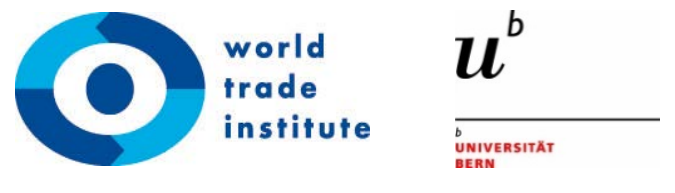

\title{
Are the Contents of International Treaties Copied-and-Pasted? Evidence from Preferential Trade Agreements
}

Todd Allee / Manfred Elsig University of Maryland / University of Bern tallee@umd.edu I manfred.elsig@wti.org

Research for this paper was funded by the Swiss National Science Foundation under a grant to the National Centre of Competence in Research on Trade Regulation, based at the World Trade Institute of the University of Bern, Switzerland.

NCCR TRADE WORKING PAPERS are preliminary documents posted on the NCCR Trade Regulation website (<www.nccrtrade.org >)and widely circulated to stimulate discussion and critical comment. These papers have not been formally edited. Citations should refer to an "NCCR Trade Working Paper", with appropriate reference made to the author(s). 


\title{
Are the Contents of International Treaties Copied-and-Pasted? Evidence from Preferential Trade Agreements
}

\author{
Todd Allee \\ Department of Government and Politics \\ University of Maryland \\ tallee@umd.edu \\ Manfred Elsig \\ World Trade Institute \\ University of Bern \\ manfred.elsig@wti.org
}

We thank Andrew Lugg for excellent research assistance and acknowledge generous financial support from the Swiss Science Foundation (www.nccr-trade.org). For helpful comments on earlier versions of this research, we thank participants at the following conferences: the 2014 and 2015 Annual Meetings of the American Political Science Association (Washington, DC and San Francisco, CA), the $8^{\text {th }}$ Annual Conference on the Political Economy of International Organizations (Berlin, Germany), and the $5^{\text {th }}$ General Conference of the European Political Science Association (Vienna, Austria). 


\section{Introduction}

A lengthy preferential trade agreement (PTA) signed in 2008 contains annexes to its government procurement chapter that list the goods, services, and entities in Canada and Colombia that are covered by the agreement's procurement rules. The sections that contain the "Schedule of Colombia" are unremarkable, except that the agreement in question is actually between Canada and Peru! Canada was indeed negotiating PTAs with both Peru and Colombia at the same time, and would sign the two agreements a week apart. This odd insertion of language about Colombia in a Canadian agreement with Peru certainly appears to be the result of sloppy copy-and-pasting between treaties.

This anecdote goes against most of what we know from literatures on bargaining, diplomacy, and international negotiation - all of which suggest that widespread copy-pasting of treaty texts is unlikely. But to some the above mistake may be unsurprising, since legal scholars frequently note the propensity for contracts to be drawn from standard or "boilerplate” language. Likewise, scholarship from international relations and international law increasingly alleges that new treaties are produced from models and that emulation is common. Empirical evidence of wholesale copy-pasting of treaty text is scant, however. Thus the primary question we explore in this research note is whether significant portions of important international treaties are copiedand-pasted from one agreement to the next?

To answer this question, we systematically compare the texts of several hundred agreements that address a common issue, in our case trade liberalization. Utilizing a novel and appropriate type of text analysis, our analyses reveal that most PTAs copy verbatim a sizeable majority of their content from an existing agreement. In fact, at least 100 PTAs take $80 \%$ or 
more of their contents word-for-word from an earlier treaty, with many copying 95\% or more. Copy-pasting is even more pronounced when we compare the main substantive provisions of trade agreements - such as chapters on antidumping, services, or intellectual property - where we regularly find chapters that are copied in their entirety from a pre-existing treaty. These findings are highly robust to different methods of comparison and the copy-paste percentages are somewhat conservative. Additionally, we reveal that copy-pasting is most prevalent in two distinct scenarios: low-capacity governments that turn to an existing template to help devise their agreements, and powerful states that desire to spread their preferred set of rules globally.

Our study represents a new approach to studying international agreements - one which leverages text analysis in a meaningful way and has several important implications. First and foremost, our findings re-shape how we think about processes of international cooperation. Governments do not painstakingly craft their agreements line-by-line, but instead lift large amounts of text from elsewhere as a shortcut. They may clash over whose past template to use, but this is a fundamentally different process, with different implications, than the classical, idealized version of negotiations. Additionally, copy-pasting from past agreements can have important, sometimes negative, consequences. Taking language "off the shelf" may lower the cost of international agreement-making for small or low-capacity countries, but it also leads to the replication and spread of treaty language that was devised by powerful states to suit their own agendas. Furthermore, what is viewed as "boilerplate" language (Gulati and Scott 2012) can have unforeseen consequences (Radin 2013), such as when governments that included seemingly mundane investor-state dispute settlement (ISDS) language in their investment agreements later were subject to billion-dollar arbitration actions (Poulsen 2015). A final implication of widespread copy-pasting is that various de-centralized treaty regimes, such as those for trade and 
investment, may be less fragmented than often assumed (Drezner 2009). This is because of the continued replication, and even convergence, of treaty language.

In sum, this research presents compelling evidence about how prominent global agreements are produced primarily through copy-pasting. This recasts our understanding of how international agreements arise and how they vary, and should spark additional research on the ways in which copy-paste dynamics affect international cooperation.

\section{Evolving Perspectives on International Treaty-Making}

Most of what we know from existing scholarship in international relations would seem to cast doubt on the idea of widespread copy-pasting of treaty texts. Diplomatic interactions involve different actors (political leadership, bureaucrats, foreign diplomats, global civil servants) in different venues (bilateral, multilateral, conferences, summits, and ad hoc negotiations) - all of which suggests agreement heterogeneity (Cooper, Heine and Thakur 2013, parts II and III). Negotiation inputs ranging from structural features such as bargaining power to the individual styles and skills of negotiators also should lead to further variation in negotiated outcomes (e.g., Berton, Kimura, and Zartman 1999; Starkey, Boyer, and Wilkenfeld 2005). The duration of negotiations also varies, and can affect the length, content, and complexity of a resulting agreement. Likewise, there exist many game-theoretic portrayals of international bargaining, often within the context of international institutions (see Gilligan and Johns 2012), in which governments exchange offers in an attempt to reach a mutually-acceptable solution within some policy space (e.g., Fearon 1995). Each instance of cooperative bargaining - even when addressing the same substantive issue (i.e., trade) - should produce unique outcomes because the 
actors differ in number or by "type," and face varying levels of incomplete information or domestic political constraints.

But we see room for compatibility between the above portrayals and possible copypasting dynamics. Bargaining offers could be based on templates, for instance. Also, different negotiation inputs might map onto a more finite set of possible treaty outcomes. In this research note, we identify and advance an emerging account of international agreement-making in which copy-pasting is more systematic than anyone realizes. Our starting point is legal scholarship on contracting as well as nascent scholarship in international relations on emulation and treaty models. These literatures acknowledge that agreements are not entirely homogenous, but expect less variation and more consistency across agreement terms due to a heavy reliance on models, templates, and recycled language.

The body of scholarship that most directly informs this perspective is the legal literature on contracting. Standard-form contracts, which can be thought of as a template, are widely used in domestic law. Across a variety of settings, the actors that write up any type of legal document will rely heavily on standard or boilerplate language from an existing document (e.g., Ben-Sharar and White 2006; Gulati and Scott 2012; Kahan and Klausner 1997; Radin 2013). Within the contracting literature, then, the use of templates is a fact of life - a seemingly ubiquitous practice for the drawing up of complex legal documents. One potential advantage is efficiency (since language can be taken "off the shelf” instead of being created from scratch) and perhaps also predictability. ${ }^{1}$ Boilerplate language also can become a focal point that is used when parties disagree on elements of a contract.

\footnotetext{
${ }^{1}$ The primary risk with relying on boilerplate language is that users may not be fully aware of what they are specifying or its myriad future consequences (Radin 2013).
} 
Gulati and Scott's (2012) study of the prevalence of so-called "boilerplating” in sovereign debt contracts is a particularly relevant application. They interview hundreds of lawyers at firms that write sovereign debt contracts and find that new contracts are produced in minutes from boilerplate ones - even when there are compelling reasons to modify or tailor contracts more carefully. They offer several possible reasons for the prevalence of boilerplating, including but not limited to: satisficing, other cognitive biases and limitations, risk aversion, organizational routine, free riding, and complexity. One can see how many of these ideas could apply to international negotiations, with negotiators being asked to negotiate multiple treaties at once, a foreign ministry following standard operating procedures, or underfunded bureaucracies reaching for existing treaty models.

Within the realm of international politics, those who study bilateral investment treaties (BITs) increasingly acknowledge the presence of models and the possible use of templates. Many governments now devise their own “model BIT” (Brown 2013; Dolzer and Schreuer 2012; UNCTAD 2015), with the idea that it will be used as the basis for future negotiations with partners. ${ }^{2}$ Qualitative and quantitative empirical evidence confirms that much of the text from a country's model can be found in the actual treaties they negotiate with a partner (Allee and Lugg 2016b; Brown 2013). Governments also may rely on past treaties or others' models (Alschner and Skougarevskiy 2016; Poulsen 2015), which can have negative or even disastrous consequences. Poulsen's (2015) compelling account of the negative effects of BITs on developing countries, in fact, is based on the premise that developing countries are copying the treaty models of Western countries, despite more applicable models and incentives to do otherwise (see Ofodile 2013).

\footnotetext{
${ }^{2}$ The practice dates back nearly three decades to the first U.S. model BIT (Vandevelde 1992), although dozens of countries now produce their own models (see Brown 2013).
} 
Recent scholarship on PTAs, defined broadly to include regional organizations, emphasizes that some international institutions serves as models for others. Multiple studies focus on how E.U. institutions serve as a models for other regional agreements (e.g., Alter 2012; Börzel and Risse 2012; Jetschke and Lenz 2013; Jetschke and Murray 2012; Lenz 2012). Likewise, Arnold and Rittberger (2013) argue that the design of the Mercosur's dispute settlement system was inspired by both the World Trade Organization's legal system and the European Court of Justice and Rühl (2012) similarly shows that the dispute settlement mechanisms (DSMs) of the WTO and NAFTA have served as models for other DSMs. Some have identified other possible templates in PTAs (Estevadeordal et al. 2009), whether for certain issue areas or regions (Elsig and Serrano 2014; Fink and Molinuevo 2008). Also applicable is recent work by Baccini, Dür and Haftel (2015), in which they use cluster analysis on multiple variables to identify the consistent presence of three post-war PTAs types or "models" (an E.U. model, a U.S./NAFTA model, and a "Southern” model) across the universe of post-war PTAs.

The above studies provide a solid foundation for our expectation of widespread copypasting of international treaties. We advance this perspective in two ways. Our first and primary contribution is empirical. Existing evidence for the use of models and templates in international negotiations tends to be confined to single cases or limited settings. That agreements are copied from past models is often more of an assumption than something that is demonstrated empirically. Thus our primary motivation in this research is to examine, and show as clearly as possible, the extent to which international treaty-making is characterized by copy-pasting.

A second contribution is theoretical. In the process of exploring empirical patterns of copy-pasting, we put forward and explore some of the reasons why such replication might occur. We believe that international negotiations should function like other settings in which complex 
contracts are written. Governments are unlikely to negotiate from scratch; doing so is both cumbersome and unnecessary. All sides enter into negotiations with a clear sense of what they want included in a new agreement, which is likely to have been formulated previously in some type of draft treaty or past agreement. These existing documents already contain precise language and formulations that have been well-vetted. Thus, as it is for those who write sovereign debt contracts, it is easier to work off an existing document than to write an entirely new one. Even if parties disagree on the appropriate language, it still is easier to work from - and modify - a fully formulated document(s) than to start from scratch.

We therefore offer a few conjectures for when we expect large-scale copy-pasting of past language to occur. First, we expect powerful states to be more likely to copy-paste heavily - and to do so from their own past agreements. Such actors have a more clearly-formulated vision of what they want in an agreement, a greater likelihood of having a past agreement or explicit template to draw from, and the bargaining leverage to get what they want. Relatedly, we generally expect actors to copy-paste from their own previous documents whenever possible, since they are more accessible and more likely to reflect their preferences. Second, we expect inexperienced and/or low-resource governments to utilize an existing template as a way to address their lack of knowledge or limited diplomatic capacity. They may recycle language from their own past agreements, if available, or emulate language devised by others - particularly if those others are similar geographically, economically, or culturally (e.g., Elkins, Guzman and Simmons 2006). Finally, we expect copy-pasting to increase over time, as certain templates become popular and are replicated regularly. 


\section{Empirical Tests}

Our analyses align, but are distinct from, other recent efforts to differentiate among the features of seemingly-similar international institutions. During the past fifteen years, scholars have put forward various institutional design arguments (e.g., Goldstein et al. 2000; Koremenos, Lipson and Snidal 2001) and applied them empirically to treaties (Koremenos 2013), regional organizations (Acharya and Johnston 2007; Haftel 2012), and international organizations generally (Tallberg et al. 2015). A wave of quantitative empirical studies has employed numeric indicators to code variation across different types of international agreements. PTAs have been coded most extensively, whether across multiple issues (Dür, Baccini and Elsig 2014) or subsets such as trade remedies (Kucik 2012), competition provisions (Bradford and Büthe 2015), nontrade issues (Milewicz et al. 2014) and dispute settlement mechanisms (Jo and Namgung 2012, Smith 2000). Variation across BITs also is now being coded, particularly in terms of dispute settlement or overall treaty strength (Allee and Peinhardt 2010, 2014; Berger et al. 2010; Neumayer et al. 2014). Similar data collection efforts have been launched to capture variation across environmental treaties (Bernauer et al. 2013).

We likewise acknowledge the heterogeneity of institutions like PTAs, yet our approach to comparing the contents of these agreements differs in a few key respects. First, we look for similarities as compared to just differences. A concern is that observable variation could be overemphasized at the expense of obvious areas of convergence. Second, we examine the entire contents of international agreements as compared to a particular section. More narrowly-focused studies and data collection efforts are incredibly valuable; sometimes, however, it is important to consider the entire forest and not just the trees. Third, we consider the text of treaties to be data itself, as compared to distilling it into one or more numeric variables. This provides a new 
analytical vantage point, and is the most appropriate way to ascertain whether the contents of treaties are being replicated en masse.

\subsection{Methodology}

Political scientists increasingly use "text as data" methodologies to extract pieces of information from text documents for purposes of classification or scaling (e.g., Grimmer and Stewart 2013). Although less prominent in the study of international relations, we argue that certain text-analysis methods are quite valuable for studying purposeful written documents such as international treaties (see Allee and Lugg 2016a; Spirling 2012). We employ an approach similar to that used by those investigating plagiarism, in which we search for perfectly-matching strings of text that would indicate "copy-pasting" from some other document. The closest parallel to our empirical approach is a series of studies that compare the text of opinions written by U.S. Supreme Court justices to lower-court opinions and written briefs submitted by those interested in the case (e.g., Collins et.al. 2013; Corley et.al. 2011; Feldman 2015).

We analyze the text of PTAs, which are a logical choice for many reasons. They are numerous, signed by nearly all countries (including all members of the World Trade Organization), and perhaps the most consequential of all international agreements. They are important politically, as evidenced by the emphasis on them in the current U.S. election campaign, and have been studied extensively by scholars, particularly those who emphasize institutional design. If anything, they present a demanding test for discovering copy-pasting because of their salience, the different attitudes and priorities that governments have toward them, and the fact that they often take years to negotiate. 
We compare the complete texts, and relevant subsets, of 378 PTAs signed during the postwar period 1954-2013. We first prepare the texts in a few common-sense ways. We omit a limited number of agreements that involve a micro-states or non-sovereign territories, have limited scope (i.e., services only), or are merely supplemental protocols. To facilitate analysis, we convert the .pdf versions of the agreements to plain text format. ${ }^{3}$ We compare treaties in a common language (English), but emphasize that the overwhelming majority of treaties are concluded in English and many remaining ones are available in both English and another language. ${ }^{4}$ To avoid biasing results systematically, we eliminate the initial and concluding sentences of each document (which provide unique location, date, and other information) and eliminate any annexes (for the minority of agreements that have them), unless a particular annex contains substantive content that in other PTAs is included in the main text (articles and chapters). ${ }^{5}$ Finally, we compare each agreement only to those PTAs that were signed previously or contemporaneously, to reflect the available templates at the time.

To identify identical text, we require that the text between two agreements matches: 1) literally word-for-word (with no deviations), and 2) for sequences of six or more words. Requiring that text be the exact same, and in the same order, signifies that it has been copypasted from elsewhere instead of just inspired by or re-written from an earlier document. ${ }^{6}$ Furthermore, requiring six words or more ensures that everyday words alone cannot constitute a

\footnotetext{
${ }^{3}$ In about a dozen cases a treaty text was damaged and we could not repair it or identify an undamaged alternative. Other than being more likely to happen for much older treaties, we do not observe any patterns in terms of the PTAs in which this occurs.

${ }^{4}$ In two-language agreements there typically is a clause stating that the in case of divergence the English-language text will prevail.

${ }^{5}$ Annexes, when they exist, typically contain limited and somewhat esoteric language and data on rules of origin, tariff schedules, etc. Product descriptions in tariff schedules are harmonized, so including them would likely bias upward our conclusions about text overlap.

${ }^{6}$ In order to ensure accurate matching, we ignore numbers and Roman numerals (and accompanying punctuation) that are used in headings and lists, since these vary from treaty to treaty in idiosyncratic ways.
} 
match, ${ }^{7}$ and is consistent with past research. ${ }^{8}$ We believe these core parameters constitute a relatively conservative approach toward estimating the amount of text that is copy-pasted, but emphasize that our finding remain robust when we specify more liberal or more restrictive rules (as we show in Table 2). To carry out our comparisons, we utilize Wcopyfind 4.1.4, a program written by Bloomfield (2014) that allows for large-scale comparisons of texts and allows us to specify the match parameters. To calculate the percentage of content in one treaty that is taken from another, we take the number of matching words (based on the two parameters above) and divide it by the total number of words in the agreement being analyzed.

\subsection{Findings}

Our analyses show quite powerfully that much of the language in PTAs is indeed copied directly from other treaties. Most PTAs take half or more of their contents verbatim from another single agreement. More than 100 of them copy $80 \%$ or more of the text from another source, and nearly 50 copy $90 \%$ or more of their contents word-for-word from another treaty. These results are highly robust and rise even further when we compare substantive chapters of the agreements to one another.

\footnotetext{
${ }^{7}$ Most common phrases are shorter than six words and thus are not counted. However, even longer common phrases such as "This article is without prejudice to" would comprise only .006\% $(6 / 100,000)$ of a document containing 100,000 words, a typical length for a PTA.

${ }^{8}$ Other social science applications also match on six words (e.g., Eshbaugh-Soha 2013; Corley, Collins, and Calvin 2011).
} 
Figure 1: Overlap between Each PTA and Closest Pre-Existing PTA

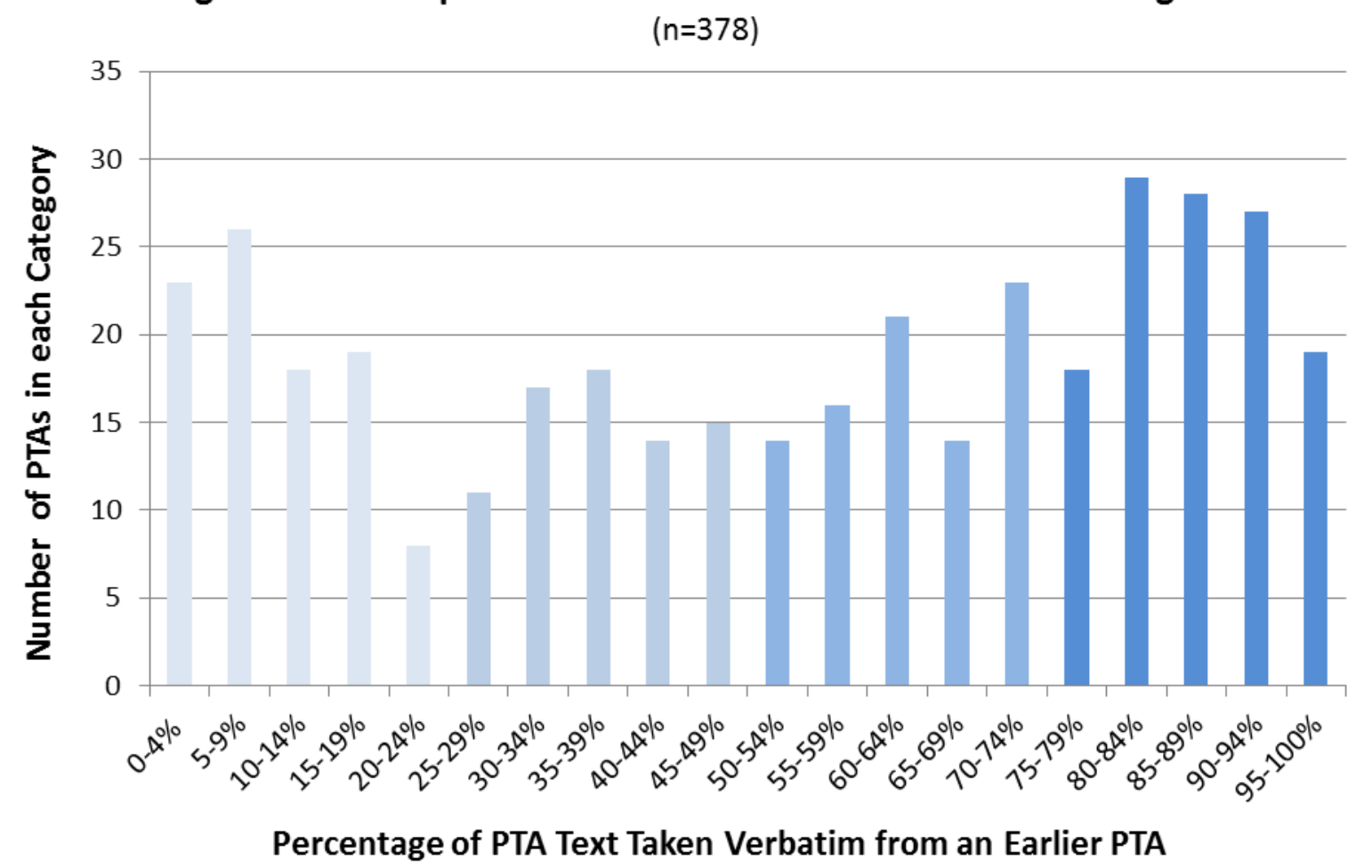

For each of the 378 PTAs we analyze, we first identify the percentage of text that is taken verbatim from its closest match among existing PTAs. The results are striking. Figure 1 shows the distribution of maximum-match percentages for all of the treaties. Overall we find that the median treaty among our 378 takes a sizeable $56 \%$ of its text verbatim from its closest treaty match - not to mention any other heavily-overlapping treaties. Overall the distribution is tilted heavily toward the upper bound. ${ }^{9}$ Looking at Figure 1, the modal categorical outcome is for a PTA to take $80-84 \%$ of its text from a single source treaty. Moreover, the three most common categorical options depicted in Figure 1 all entail a PTA drawing between $80-94 \%$ of its text from an existing source.

\footnotetext{
${ }^{9}$ Interestingly, we observe that a significant number of PTAs that overlap relatively little with another treaty fall in the lowest overlap range (0-20\%) instead of more moderate ranges (20-50\%). Further inspection reveals a diverse subset of treaties that appear somewhat isolated in that they occur early in our time period, in years with relatively little activity, or among countries that sign no other PTAs.
} 
Figure 2 hones in on the upper quartile of the distribution in Figure 1, depicting the number of treaties that overlap at various percentage-levels between $75-99 \%$. Taking in all of Figure 2, we see more than 120 PTAs copy three-quarters or more of their content word-forword from another agreement. At the higher end, 46 PTAs copy 90\% or more of their language from another, single treaty - with five taking a staggering 99\%. The modal value within Figure 2 is for a PTA to copy $90 \%$ of its contents word-for-word from a "source” agreement.

\section{Figure 2: Distribution of Agreements that Copy the Most Text from another Agreement}

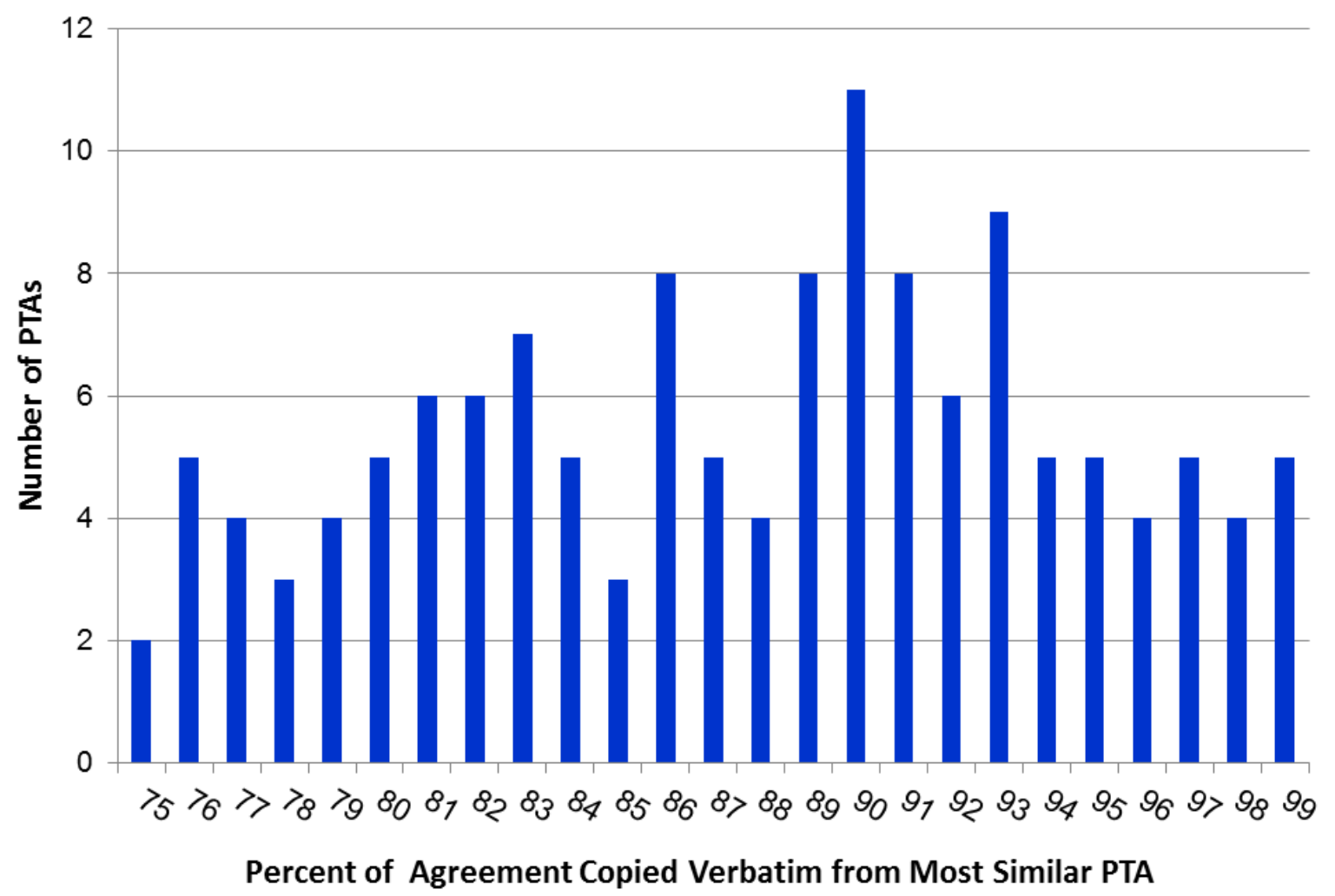

These overlap numbers also are robust. Our primary method of comparison requires six or more consecutive words to be replicated perfectly to constitute a "match.” To check for robustness we re-estimate the comparisons after varying both parameters. First, we relax the 
requirement that the match be "perfect" and instead allow for close but not verbatim matches. ${ }^{10}$ Second, we vary the number of words needed to create a match, in both less (four) and more (eight, ten) restrictive directions. The results are shown in Table 1. One immediate take-away is that the finding of widespread copy-pasting is highly stable. Five of the seven re-estimations produce a $3 \%$ or less change in the average copy-paste percentage. Allowing for inexact matches, for instance, produces only a modest $2.5 \%$ increase in the average copy-paste percentage, ceteris paribus. Even at the extremes of varying both matching parameters, the average overlap percentage only varies (increases) by around 8\%. The effects of modifying match parameters are modest overall, and the fact that more demanding requirements for matching are largely inconsequential increases our confidence in our original approach.

\section{Table 1: Sensitivity Check for Alternate Text-Match Parameters}

\begin{tabular}{|c|c|}
\hline Match Specifications & $\begin{array}{c}\text { Effect on Average Overlap Percentage } \\
\text { (baseline is 6 words, Exact match) }\end{array}$ \\
\hline 4 words, Close match & $+8.5 \%$ \\
\hline 4 words, Exact match & $+5.8 \%$ \\
\hline 6 words, Close match & $+2.5 \%$ \\
\hline 8 words, Close match & $+.2 \%$ \\
\hline 6 words, Exact match (baseline) & --- \\
\hline 10 words, Close match & $-.9 \%$ \\
\hline 8 words, Exact match & $-2.3 \%$ \\
\hline 10 words, Exact match & $-3.3 \%$ \\
\hline
\end{tabular}

\footnotetext{
${ }^{10}$ To comprise a close match, $80 \%$ of the text in a segment (of any length) must match exactly, but up to five words in the segment may be distinct.
} 
These large and stable numbers are somewhat conservative for another reason. For our copy-paste percentages, we report the amount of text drawn from a single, existing treaty - the treaty with the greatest overlap with the PTA being analyzed. We do this for simplicity and consistency, and because available computational options are based on pairwise comparisons. Yet there often are additional treaties - the second-, third-, or even tenth-best matches - that also overlap significantly with the treaty in question. If we were able to cycle through each subsequent close match, we would generate a higher overall copy-paste percentage as we locate additional text in other treaties (not found in the closest treaty-match) that is utilized in the new treaty. Although this is not possible, for each PTA we can examine the next-closest treaty matches to see how much is copied from them.

Figure 3 illustrates how much overlapping text is found in the second- and third-closest PTA matches, in addition to the closest match. In a few cases it is a clear that a single treaty is the dominant source of the copied language - with the next-closest match falling to the level of $70 \%$ overlap or just below. Yet in the sizeable majority of cases there is relatively little "drop off," with second- and even third-best matches overlapping to the tune of $80-90 \%$ or more. Thus, even if the closest-match did not exist, the subsequent PTA might still look a lot like various other PTAs. It is difficult to disentangle fully this web of reinforcing text overlap. Nevertheless, once one moves beyond the single largest source for a given PTA's borrowed text, several other treaties likely "fill in" at least some of the remaining uniqueness. This adds further evidence to the conclusion that on average the vast majority of text in a PTA is copy-and-pasted verbatim from one or more pre-existing agreements. 


\section{Figure 3: Amount of Text Shared with Top 3 Treaty Matches (among PTAs that copy most heavily)}

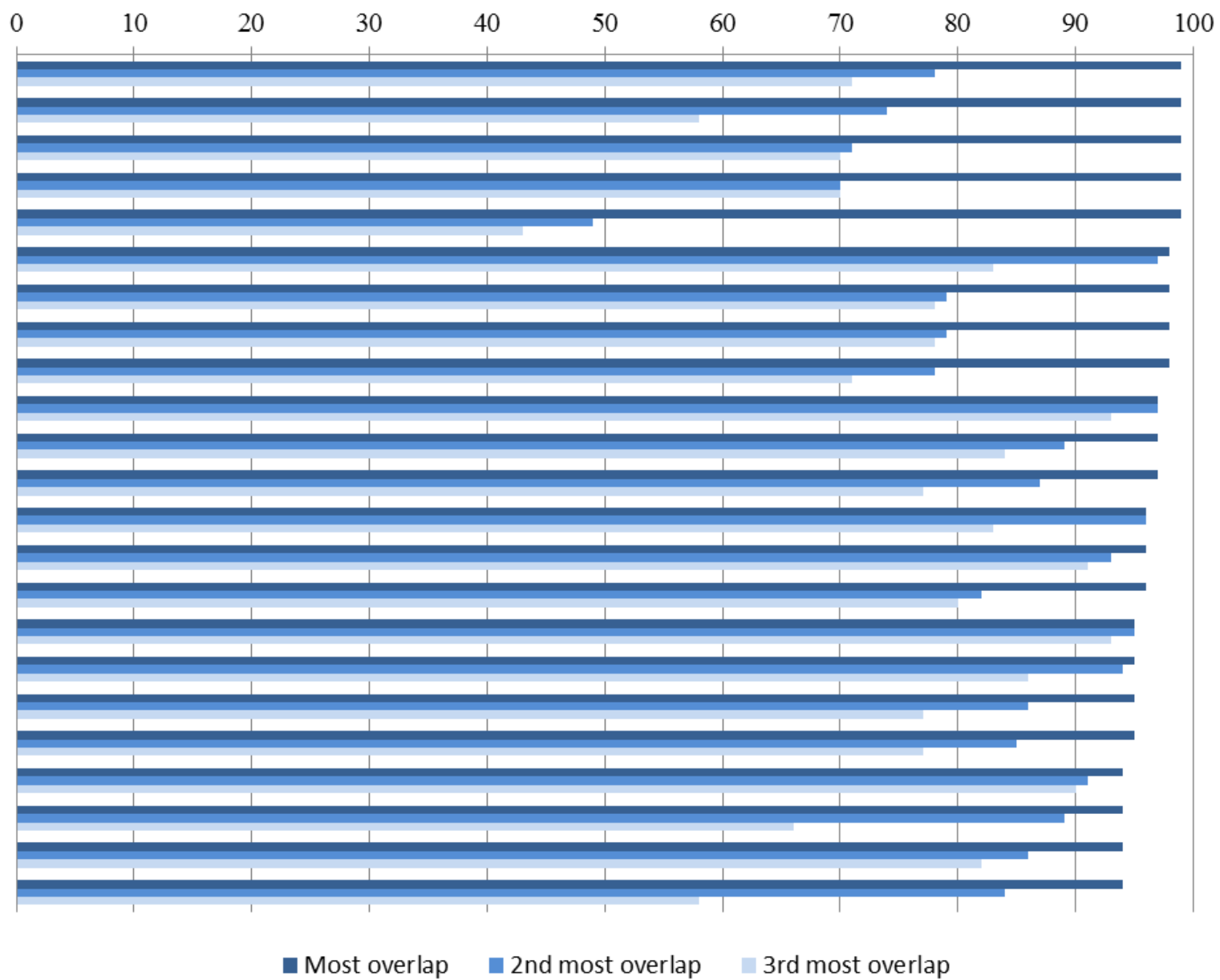

Next we investigate and compare the substantive chapters of PTAs to see how much they are copy-pasted from earlier chapters. We identify fifteen trade areas that are most commonly addressed in PTAs, all of which will be familiar to trade scholars. ${ }^{11}$ For each PTA that addresses a given trade issue, we isolate all of the text from the relevant chapter as well as any text elsewhere in the PTA that directly concerns the same topic. We then re-estimate our comparisons

\footnotetext{
${ }^{11}$ The fifteen areas include: antidumping, dispute settlement, safeguards, sanitary and phyto-sanitary measures, intellectual property, technical barriers to trade, government procurement, services, investment, labor, financial services, e-commerce, telecommunications, movement, and the environment.
} 
on the texts of each of the fifteen substantive trade topics, using the same specifications discussed earlier.

Table 2: Median and Maximum Amount of Text Shared with Closest Treaty Match by Trade Topic

\begin{tabular}{|c|c|c|c|}
\hline $\begin{array}{c}\text { Part of PTA that is } \\
\text { being Compared }\end{array}$ & $\begin{array}{l}\text { Median } \\
\text { Overlap }\end{array}$ & Max Overlap & $\mathbf{n}$ \\
\hline Complete Text & $56 \%$ & $99 \%$ & 378 \\
\hline Antidumping & $88 \%$ & $100 \%$ & 261 \\
\hline Procurement & $86 \%$ & $100 \%$ & 194 \\
\hline Safeguards & $80 \%$ & $100 \%$ & 327 \\
\hline Services & $77 \%$ & $100 \%$ & 184 \\
\hline Labor & $74 \%$ & $99 \%$ & 24 \\
\hline Intellectual Property & $72 \%$ & $100 \%$ & 218 \\
\hline Sanitary and Phyto-Sanitary & $71 \%$ & $100 \%$ & 217 \\
\hline Financial Services & $70 \%$ & $100 \%$ & 61 \\
\hline Technical Barriers & $68 \%$ & $100 \%$ & 221 \\
\hline E-Commerce & $67 \%$ & $100 \%$ & 45 \\
\hline Dispute Settlement & $66 \%$ & $100 \%$ & 366 \\
\hline Investment & $65 \%$ & $100 \%$ & 177 \\
\hline Telecommunications & $64 \%$ & $100 \%$ & 64 \\
\hline Movement & $50 \%$ & $97 \%$ & 82 \\
\hline Environment & $50 \%$ & $100 \%$ & 56 \\
\hline $\begin{array}{l}\text { Average across all fifteen } \\
\text { sub-issues }\end{array}$ & $70 \%$ & - & 378 \\
\hline
\end{tabular}

The findings summarized in Table 2 reveal that on average the substantive areas exhibit even stronger copy-and-paste dynamics as compared to the full treaty texts. For ten of the trade 
areas the median PTA copies two-thirds or more of a given chapter directly from the chapter in another PTA. For three areas the median amount copied is $80 \%$ or more. If we sum across all fifteen areas, we see that on average $70 \%$ of the substantive content of a PTA is taken verbatim from another treaty. These elevated numbers make sense because these topics represent the core of the agreements. Perhaps most striking are the findings for maximum copy-paste values. Across 12 of the 15 trade topics we uncover one or more PTAs that copies an entire substantive chapter directly from a pre-existing agreement. The three other areas have at least one PTA that copies $97 \%$ or more of its chapter from another PTA.

Table 2 also reveals that the most highly-evolved trade areas are those where copypasting is greatest. This includes topics such as antidumping and safeguards, which have been addressed in trade agreements (WTO and early-generation PTAs) for decades. By contrast, we see less borrowing of text on newer trade topics such as the environment, movement, and telecommunications. These findings make sense: the more well-established trade topics appear in more PTAs and have more past chapters that can serve as templates, whereas templates are less developed on the newer issues. Also, over time certain templates for a given issue are likely to "win out" and become more heavily replicated. This, then, leads to greater convergence of treaty language in these areas.

The above discussion raises the interesting issue of whether we are witnessing more or less convergence over time in terms of what is being specified in agreements such as PTAs. An increasing worry for many is that the shift from multilateral to regional or bilateral cooperation is leading to greater legal fragmentation (e.g., Benvenisti and Downs 2007). Concerns are particularly pronounced on trade policy given the shift from the WTO to PTAs (e.g., Bhagwati 2007, Pauwelyn 2003). The primary worry is that increasing "regime complexity" (Alter and 
Meunier 2009) can weaken legal obligations and make compliance with rules more difficult (Drezner 2009).

Figure 4: Copying-and-Pasting of PTAs over Time

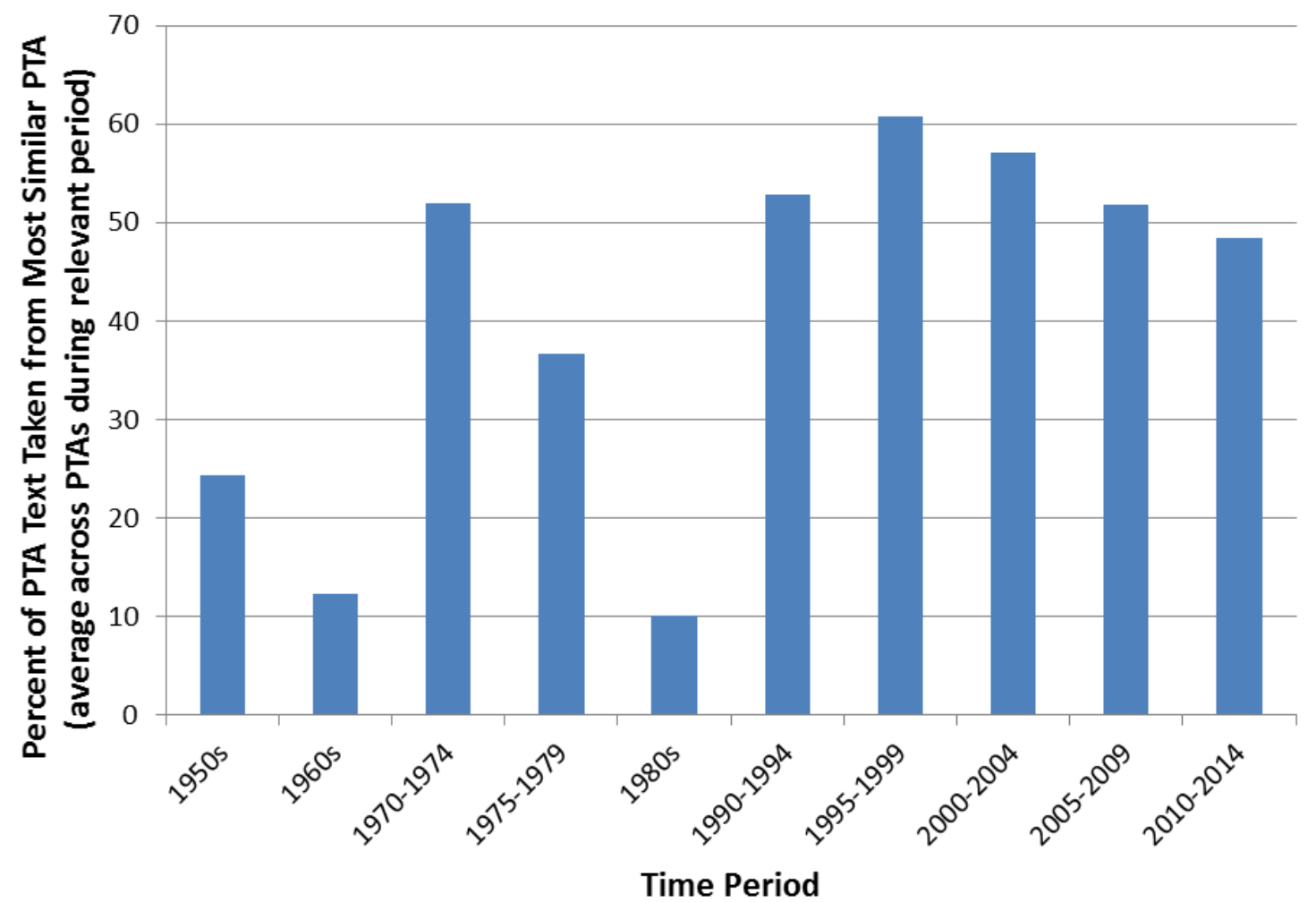

We return to the full agreement texts to see if the language in PTAs overlaps more or less over time. Figure 4 reveals that on average PTAs signed in more recent years do indeed take more content from pre-existing agreements. ${ }^{12}$ The most noteworthy pattern in Figure 4 is the high-degree of copy-pasting of text that occurs in the post-Cold War period. In periods since 1990, the average treaty has taken approximately 50-65\% of its text from a pre-existing treaty, a pattern that remains relatively consistent. This far eclipses levels of earlier years (with a brief exception in the early 1970s) when there were fewer PTAs, fewer templates, and less borrowing of language. All in all, Figure 4 indicates that despite the proliferation of agreements, the legal

\footnotetext{
${ }^{12}$ We present the totals by decade for three situations (1950s, 1960s, 1980s) in which there are a limited number of new PTAs signed in that period (ten or fewer).
} 
rules within them appear to be converging instead of diverging, thus allaying fears that international regimes are becoming more fragmented.

We now dig deeper into what exactly is being replicated from one treaty to the next. The online appendix includes several examples of copy-pasted text that reflect many of the dynamics we observe consistently. The first example highlights selections of shared text between the 1995 Armenia-Turkmenistan PTA and the Armenia-Moldova trade agreement from two years earlier which share $93 \%$ of the exact same text overall. This is one of many post-Soviet examples in our data. In this particular case, we see passages re-used word-for-word from one agreement to the next, with only minor differences in numbering, sentence structure, etc. Even small mistakes (extra spaces, missing words such as "the” or “an”) are replicated, providing further evidence that the actual transfer occurs via copy-pasting instead of re-drafting.

Additional examples, such as the United States' PTAs with Chile (2003) and later Colombia (2006), illustrate how templates are replicated from one treaty to the next with only minor modifications. The Colombia agreement (on the left) copies the same language that was used previously (Chile agreement, on the right) - occasionally adding minor tweaks in terms of proper nouns, simple language, etc. The different article numbers across the two PTAs indicate that agreements can be structured differently and be interrupted by unique content - but many core sections of the agreement are simply replicated whenever the appropriate time comes. The replicated content can be specific to one of the actors - such as the replicated sections on distinctive products such as U.S. bourbon whiskey - which illustrates that unique content, not generic legal language, is often copied. The same is true in the E.U. stabilization and association agreements with both Albania and then Montenegro, which overall share more than threequarters of the exact same language. The example in the appendix highlights the presence of 
identical, E.U-driven provisions related to combatting terrorism and treatment of other signatories of similar agreements. Finally, we see the potential for updating of templates and reproducing new contents. For instance, language on a sugar compensation mechanism, which was not in the U.S.-Chile agreement, was inserted into the PTA with Peru and then copied wordfor-word in the subsequent U.S. agreement with Panama.

The examples in the appendix also begin to paint the picture of where copy-pasting is most prevalent. In order to get a better sense of when, and by whom, copying-and-pasting is most likely to occur, we now identify the actual PTAs that borrow the most text from elsewhere. Table 3 lists the 30 PTAs that take the greatest percentage of their text from an earlier PTA. One thing that jumps out is the sizeable number of countries from central and eastern Europe. Thirteen of the first 15 PTAs in Table 3 include a country from the region, such as Albania, Bosnia-Herzegovina, Moldova, the Czech Republic, and all three Baltic states, among others. Earlier we put forward the argument that low-capacity or inexperienced countries might find it desirable to copy from an existing treaty as an efficiency shortcut. This certainly appears to be the case, based on the time periods in which these countries are doing the copying. Most of these agreements are signed in an era of political and economic transition immediately after the end of the Cold War. ${ }^{13}$ This suggests that countries that have little experience with agreement-making are more likely to use templates.

\footnotetext{
${ }^{13}$ This is the 1990s for most and 2000s for others (i.e., Bosnia-Herzegovina).
} 
Table 3: PTAs with the Most Text Taken from Another Treaty

\begin{tabular}{|c|c|c|}
\hline PTA & Year & $\begin{array}{l}\% \text { Text Taken Verbatim } \\
\text { From Most Similar Treaty }\end{array}$ \\
\hline Israel-Slovakia & 1996 & 99 \\
\hline United States-Peru & 2006 & 99 \\
\hline Czech Republic-Israel & 1996 & 99 \\
\hline Albania-Bosnia and Herzegovina & 2003 & 99 \\
\hline EC-Israel Euro-Med Association & 1995 & 99 \\
\hline Norway-Estonia & 1992 & 98 \\
\hline Turkey-Czech Republic & 1997 & 98 \\
\hline Moldova-Albania & 2003 & 98 \\
\hline Slovakia-Turkey & 1997 & 98 \\
\hline Norway-Estonia & 1992 & 97 \\
\hline Macedonia-Romania & 2003 & 97 \\
\hline EFTA-Estonia & 1995 & 97 \\
\hline Lithuania-Slovakia & 1996 & 97 \\
\hline European Community-Czech Republic & 1993 & 96 \\
\hline Slovakia-Estonia & 1996 & 96 \\
\hline Norway-Lithuania & 1992 & 96 \\
\hline European Community-Latvia & 1994 & 95 \\
\hline EFTA-Latvia & 1995 & 95 \\
\hline European Community-Norway & 1973 & 95 \\
\hline Slovakia-Latvia & 1996 & 95 \\
\hline European Community-Lithuania & 1995 & 94 \\
\hline Macedonia-Romania & 2003 & 94 \\
\hline Slovenia-Slovakia & 1993 & 94 \\
\hline Czech Republic-Latvia & 1996 & 94 \\
\hline Turkmenistan-Armenia & 1995 & 93 \\
\hline European Community-Estonia & 1995 & 93 \\
\hline European Community-Serbia & 2008 & 93 \\
\hline Czech Republic-Slovenia & 1993 & 91 \\
\hline Latvia-Norway & 1992 & 93 \\
\hline
\end{tabular}


Major actors like the United States, European Union, and European Free Trade Agreement (EFTA) partners also figure prominently, as each is found in the top 10 of Table 3. Powerful economic actors should have a clear idea of what they want in trade agreements. They are likely to come to negotiations with a template, which we expect to be accepted largely intact by a weaker partner. Table 4, which complements the previous table by showing the "dyads,” or pairs, of PTAs that have the most overlapping contents, further affirms this is the case. For instance, we identify two U.S. agreements, with Peru and Colombia, which share 99\% of the same text. Likewise, we observe three distinct pairings of PTAs that include European Union agreements on both sides, in which 95\% of the text is replicated from one E.U. agreement to the other. The same is true for two sets of dyads that include EFTA members on both sides. In all of the above cases, the partner country is much smaller economically, which further indicates that the powerful-actor template is being reproduced with little alteration. 
Table 4: PTA Pairs with the Greatest Text Overlap

\begin{tabular}{|c|c|c|c|}
\hline PTA & Year & Matching PTA & \% Overlap \\
\hline Israel-Slovakia & 1996 & Israel-Czech Republic & 99 \\
\hline United States-Peru & 2006 & United States-Colombia & 99 \\
\hline Albania-Bosnia and Herzegovina & 2003 & Albania-Moldova & 99 \\
\hline EC-Israel Euro-Med Association & 1995 & EC-Israel & 99 \\
\hline Norway-Estonia & 1992 & Norway-Lithuania & 98 \\
\hline Turkey-Czech Republic & 1997 & Turkey-Slovakia & 98 \\
\hline Romania-Macedonia & 2003 & Romania-Albania & 97 \\
\hline EFTA-Latvia & 1995 & EFTA-Estonia & 97 \\
\hline Lithuania-Slovakia & 1996 & Lithuania-Czech Republic & 97 \\
\hline Slovakia-Latvia & 1996 & Slovakia-Lithuania & 97 \\
\hline EC-Czech Republic & 1993 & EC-Slovakia & 96 \\
\hline Norway-Latvia & 1992 & Norway-Lithuania & 96 \\
\hline Estonia-Slovakia & 1996 & Estonia-Czech Republic & 96 \\
\hline Norway-Lithuania & 1992 & Norway-Estonia & 96 \\
\hline EC-Latvia & 1994 & EC-Lithuania & 95 \\
\hline Slovakia-Latvia & 1996 & Slovakia-Lithuania & 95 \\
\hline EC-Norway & 1973 & EC-Switzerland-Lichtenstein & 95 \\
\hline EFTA-Latvia & 1995 & EFTA-Estonia & 95 \\
\hline Latvia-Czech Republic & 1996 & Latvia-Slovakia & 94 \\
\hline EC-Lithuania & 1995 & EC-Latvia & 94 \\
\hline EC-Norway & 1973 & EC-Iceland & 94 \\
\hline Romania-Macedonia & 2003 & Romania-Albania & 94 \\
\hline Slovenia-Slovakia & 1993 & Slovenia-Czech Republic & 94 \\
\hline Armenia-Turkmenistan & 1995 & Armenia-Moldova & 93 \\
\hline Estonia-Slovenia & 1996 & Estonia-Slovakia & 93 \\
\hline EC Serbia & 2008 & EC Montenegro & 93 \\
\hline EC Estonia & 1995 & EC-Latvia & 93 \\
\hline Latvia-Slovakia & 1996 & Czech Republic-Lithuania & 93 \\
\hline
\end{tabular}


The dominant pattern in Table 4, in fact, is that countries regularly copy-paste from their own past treaties. Table 4 lists all PTA pairings in which one agreement replicated $93 \%$ or more of the language from another agreement. In all cases but one, the source of that material is internal; that is, one of the current signatory's past agreements. As discussed previously, in some cases this could be a power-play by an actor like the U.S. or E.U. to spread its preferred language. Norway's heavily overlapping agreements with the Baltic states also fit this pattern in which a country with more leverage appears to be having its preferred template accepted by others in bilateral agreements.

In other situations this recycling of one's own past agreements may represent an unintentional first mover advantage that is bestowed simply by having an existing PTA. As noted earlier, many of the countries common to the pairings in Table 4 are post-Cold War transition countries. As many of them signed new trade agreements, they often leaned heavily on a previous treaty that one of them had signed recently. For instance, in Armenia's agreement with Turkmenistan, the two of them borrowed heavily from Armenia's agreement with Moldova from two years earlier. The same pattern is evidenced in Romania's nearly-perfectly-overlapping treaties with Albania and then Macedonia. In cases like these, copy-pasting is likely borne of necessity and helped by having a recent treaty available.

The above patterns constitute the tip of the iceberg; the 50 or so PTAs that are nearlyperfectly copied from another source. Yet there are many other trade agreements that overlap in the range of $70-85 \%$. Therefore, we emphasize two final dynamics that exist in these cases that lie just below the surface. Here we regularly see agreements in which the parties borrow heavily not from their own past PTAs, but from a country that is similar to either or both of the current signatories. This is most evident among the Baltic countries and countries in central Europe, 
where we often see copy-pasting to the tune of $80 \%$ or more from the PTAs of one's similar neighbors. We also see instances of this in the Middle East and Latin America. Another pattern we observe is that members of major plurilateral agreements tend to use the language from that agreement in future, typically bilateral, PTAs. For instance, the countries that signed the 1992 Central European Free Trade Agreement later copied 60\% or more of that agreement into dozens of PTAs they subsequently signed with other partners. Likewise, 86\% of Canada's 1996 agreement with Chile can be traced back word-for-word to the North American Free Trade Agreement (NAFTA), which Canada had signed three years earlier.

\section{Conclusion}

In this research we advance an emerging interdisciplinary narrative about how international treaty-making occurs through copy-pasting from existing templates. We identify dozens of situations in which more than $90 \%$ of a trade agreement is lifted verbatim from a preexisting agreement, which in our view is remarkable. Some will find the numbers we present to be startling; others will view them as unsurprising. Regardless of one's perspective, we argue that our findings are noteworthy and have myriad implications.

It now appears undeniable that many of the most-frequently studied international agreements are heavily copy-pasted. This reality needs to be acknowledged and incorporated into future efforts at theorizing and carrying out empirical analyses. These copy-paste dynamics appear to be highly applicable to trade and investment agreements, which we note continue to dominate the political and diplomatic landscape, as Brexit and the U.S. presidential election attest. But the ideas are applicable to the full range of international agreements, and computational advances make it easy for others to apply our methodology to additional topic- 
areas and other diplomatic endeavors. Our approach also adds a new dimension to ongoing attempts to study design variation within international institutions. We similarly assert that the international treaties on a particular issue can and do differ, but there often is much commonality among them, which we show to be copied-and-pasted.

This reality of widespread copy-pasting has implications for international relations issues ranging from diffusion to power. There exists a vibrant literature in international relations on the diffusion of things like protests, democracy, and international agreements (e.g., Solingen 2012). Our unique contribution is to analyze the diffusion of language within the various agreements that are spreading globally. Moreover, we present an active diffusion story. Sometimes we observe pure emulation of others' language, particularly by developing countries. At other times, however, powerful actors are the drivers of diffusion as they attempt to spread their preferred trade rules globally. Yet regardless of how language travels from one agreement to the next, it can have major consequences. Just look at the experiences of countries such as Bolivia, Indonesia, and even Australia, whose use of boilerplate investment treaty language on dispute settlement resulted in them being sued by foreign investors for billions of dollars, thus prompting a re-evaluation of how they specify their treaty commitments.

Several avenues are ripe for future research, including some that we have started down already. This research note provides important, case-based evidence to answer the obvious follow-up questions of "why" and "how" treaty language spreads. We expect that systematic regression-based investigations will uncover additional evidence of capacity-driven or powerbased copy-pasting, along with some new explanations. In general, we advocate exploring in much more detail the pathways by which language travels around the globe. Governments apply what they did in their own past treaties to future ones. Their new treaty partners also may 
become part of additional chains. Thus we expect that the language in landmark agreements, such as NAFTA, early EU agreements, various WTO chapters, and perhaps the TPP, is more likely to be copied into future trade agreements. We also see the potential for exploring these links through network analysis. Although we expect all of these dynamics to be particularly applicable to PTAs and perhaps also BITs, we welcome efforts to apply them to other international institutions. Regardless of what a new treaty addresses and how it spreads, we expect that anyone who bothers to look at it carefully will see much that looks strikingly familiar. 


\section{References:}

Acharya, Amitav and Alastair Iain Johnston, eds. 2007. Crafting Cooperation: Regional Institutions in Comparative Perspective. Cambridge: Cambridge University Press.

Allee, Todd and Manfred Elsig. 2015a. Dispute Settlement Provisions in PTAs: New Data and New Concepts, in Trade Cooperation: The Purpose, Design and Effects of Preferential Trade Agreements, edited by A. Dür and M. Elsig, Cambridge: Cambridge University Press.

Allee, Todd and Manfred Elsig 2015b. Why Do Some International Institutions Contain Strong Dispute Settlement Provisions? New Evidence from Preferential Trade Agreements. Review of International Organizations 11 (1): 89-120.

Allee, Todd and Andrew Lugg. 2016a. Who Wrote the Rules for the Trans-Pacific Partnership? Research \& Politics (July-September): 1-9.

Allee, Todd and Andrew Lugg. 2016b. Do BITs Represent the Interests of Powerful States? Paper Presented at the 2016 Annual Meeting of the International Studies Association. Atlanta, Georgia.

Allee, Todd and Clint Peinhardt. 2012. "Contingent Credibility: The Reputational Effects of Investment Treaty Disputes on Foreign Direct Investment.” International Organization 65(3):1-26.

Allee Todd and Clint Peinhardt. 2014. "Evaluating Three Explanations for the Design of Bilateral Investment Treaties.” World Politics 66(1): 47-87.

Alter, Karen. 2012. The Global Spread of European Style Courts. West European Politics 35 (1):135-154.

Alter, Karen and Sophie Meunier 2009. The Politics of International Regime Complexity. Perspectives on Politics 7 (1):13-24.

Arnold, Christian and Berthold Rittberger. 2013. The Legalization of Dispute Resolution in Mercosur. Journal of Politics in Latin America 5 (3):97-132.

Baccini, Leonardo and Andreas Dür. 2012. The New Regionalism and Policy Interdependence. British Journal of Political Science 42 (1):57-79.

Baccini, Leonardo, Andreas Dür and Yoram Haftel. 2015. Imitation and Innovation in International Governance: The Diffusion of Trade Agreement Design. In Trade Cooperation: The Purpose, Design and Effects of Preferential Trade Agreements, edited by A. Dür and M. Elsig, Cambridge: Cambridge University Press

Ben-Sharar, Omri and James J. White. 2006. Boilerplate and Economic Power in Auto Manufacturing Contracts. Michigan Law Review 104 (5):953-982. 
Benvenisti, Eyal and George Downs. 2007. The Empire's New Clothes: Political Economy and the Frag-mentation of International Law. Stanford Law Review 60 (2):595-631.

Berger, Axel, Matthias Busse, Peter Nunnenkamp \& Martin Roy. 2010. Do Trade and Investment Agreements Lead to More FDI? Accounting for Key Provisions Inside the Black Box. Kiel Working Paper, No. 1647.

Bernauer, Thomas, Anna Kalbhenn, Vally Koubi \& Gabriele Spilker. 2013. Is There a 'Depth Versus Participation' Dilemma in International Cooperation? Review of International Organizations 8 (4):477-497.

Berton, Peter, Hiroshi Kimura, and I. William Zartman, eds. International Negotiation: Actors, Structure/Process, Values. New York, St. Martin’s Press.

Bhagwati, Jagdish 2008. Termites in the Trading System: How Preferential Agreements Undermine Free Trade. Oxford: Oxford University Press.

Bloomfield, LA (2014) WCopyfind 4.1.4. Available at: http://plagiarism.bloomfieldmedia.com/zwordpress/software/wcopyfind/

Börzel, Tanja and Thomas Risse. 2012. From Europeanisation to Diffusion: Introduction. West European Politics 35 (1):1-19.

Bradford, Anu and Tim Büthe. 2015. Competition Policy and Free Trade: Antitrust Provisions in PTAs. In Trade Cooperation: The Purpose, Design and Effects of Preferential Trade Agreements,” edited by A. Dür and M. Elsig, Cambridge: Cambridge University Press

Brown, Chester. 2013. Commentaries on Selected Model Investment Treaties. Oxford: Oxford University Press.

Collins, Paul M., Pamela C. Corley, and Jesse Hanmer. 2013. The Influence of Amicus Curiae Briefs on U.S. Supreme Court Opinion Content. Paper presented at the $109^{\text {th }}$ Annual Meeting of the American Political Science Association. Chicago, IL.

Cooper, Andrew F., Jorge Heine, and Ramesh Thakur. 2013. The Oxford Handbook of Modern Diplomacy. Oxford: Oxford University Press.

Corley, Pamela C., Paul M. Collins, Jr., and Bryan Calvin. 2011. Lower Court Influence on U.S. Supreme Court Opinion Content. Journal of Politics 73 (1):31-44.

Dolzer, Rudolf, and Christoph Schreuer. 2012. Principles of International Investment Law, $2^{\text {nd }}$ ed. Oxford: Oxford University Press.

Drezner, Daniel 2009. The Power and Peril of International Regime Complexity. Perspectives on Politics 7(1): 65-70. 
Dür, Andreas, Leonardo Baccini and Manfred Elsig. 2014. The Design of International Trade Agreements: Introducing a New Dataset. Review of International Organizations 9(3):353-375.

Elkins, Zachary, Andrew Guzman, and Beth Simmons. 2006. "Competing for Capital: The Diffusion of Bilateral Investment Treaties, 1960-2000.” International Organization 60 (4):81146.

Elsig, Manfred and Cédric Dupont. 2012. "European Union Meets South Korea: Bureaucratic Interests, Exporter Discrimination and the Negotiations of New Trade Agreements." Journal of Common Market Studies 50(3):492-507.

Elsig, Manfred and Omar Serrano. 2014. "Emerging Powers and Trade Remedy Laws: Design and Application.” Paper presented at the ISA's 55th Annual Convention, Toronto, Canada.

Eshbaugh-Soha M. 2013. Presidential influence of the news media: the case of the press conference. Political Communication 30 (4):548-564.

Estevadeordal, Antoni, Kati Suominen and Robert Teh, eds. 2009. Regional Rules in the Global Trading System. Cambridge: Cambridge University Press.

Fearon, James. Rationalist Explanations for War. International Organization 49 (3):379-414.

Feldman, Adam. A Brief Assessment of Supreme Court Opinion Language.” Available at: SSRN: http://ssrn.com/abstract=2574451

Fink, Carsten and Martin Molinuevo. 2008. East Asian Preferential Trade Agreements in Services: Liberalization Content and WTO Rules. World Trade Review 7 (4):641-673.

Gilligan, Michael J. and Leslie Johns. 2012. Format Models of International Institutions. Annual Review of Political Science 15: 221-243.

Goldstein, Judith, Miles Kahler, Robert Keohane, and Anne-Marie Slaughter. 2000. Introduction: Legalization and World Politics. International Organization 54 (3):385-99

Grimmer, Justin and Brandon M. Stewart. 2013. Text as Data: The Promise and Pitfalls of Automatic Content Analysis Methods for Political Texts. Political Analysis 21 (3):267-297.

Gulati, Mitu and Robert E. Scott. 2012. The Three and a Half Minute Transaction: Boilerplate and the Limits of Contract Design. Chicago: University of Chicago Press.

Haftel, Yoram. 2012. Regional Economic Institutions and Conflict Mitigation. Ann Arbor: University of Michigan Press.

Jetschke, Anja and Tobias Lenz. 2013. Does Regionalism Diffuse? A New Research Agenda for the Study of Regional Organizations. Journal of European Public Policy 20 (4):626-637. 
Jetschke, Anja and Philomena Murray. 2012. Diffusing Regional Integration: the EU and Southeast Asia. West European Politics 35 (1):174-191.

Jo, Hyeran and Hyun Namgung. 2012. Dispute Settlement Mechanisms in Preferential Trade Agreements: Democracy, Boilerplates, and the Multilateral Trade Regime. Journal of Conflict Resolution 56 (6):1041-68.

Kahan, Marcel and Michael Klausner. 1997. Standardization and Innovation in Corporate Contracting (Or, the 'Economics of Boilerplate'). Virginia Law Review 83 (4):713-770.

Koremenos, Barbara. 2013. The Continent of International Law. Journal of Conflict Resolution 57 (4):653-681.

Koremenos, Barbara, Charles Lipson and Duncan Snidal. 2001. The Rational Design of International Institutions. International Organization 55(4):761-799.

Kucik, Jeffrey. 2012. The Domestic Politics of Institutional Design: Producer Preferences over Trade Agreement Rules. Economics \& Politics 24 (2):95-118.

Lenz, Tobias. 2012. Spurred Emulation: the EU and Regional Integration in Mercosur and SADC. West European Politics 35 (1):155-173.

Milewicz, Karolina, James Hollway, Claire Peacock and Duncan Snidal. 2014. Beyond Trade: How Powerful States Use PTAs to Leverage Non-Trade Objectives. Paper presented at the Annual Meeting of the American Political Science Association, Washington DC.

Neumayer, Eric, Peter Nunnenkamp, and Martin Roy. 2014. Are Stricter Investment Rules Contagious? Host Country Competition for Foreign Direct Investment Through International Agreements. Kiel Working Paper, No. 1910.

Ofodile, Uche Ewelukwa. 2013. Africa-China Bilateral Investment Treaties: A Critique. Michigan Journal of International Law 35 (1):131-211.

Pauwelyn, Joost 2003. Conflict of Norms in Public International Law: How WTO Law relates to Other Rules of International Law. Cambridge: Cambridge University Press.

Poulsen, Lauge N. Skovgaard. 2015. Bounded Rationality and Economic Diplomacy: The Politics of Investment Treaties in Developing Countries. Cambridge: Cambridge University Press.

Poulsen, Lauge N. Skovgaard. 2014. Bounded Rationality and the Diffusion of Modern Investment Treaties. International Studies Quarterly 58 (1):1-14.

Radin, Margaret J. 2013. Boilerplate: The Fine Print, Vanishing Rights, and the Rule of Law. Princeton: Princeton University Press. 
Rühl, Johannes. 2012. Which Model Diffuses? Designing the Mercosur Dispute

Settlement Mechanism. Manuscript, Graduate Institute of International and Development Studies, Geneva.

Smith, James McCall. 2000. The Politics of Dispute Settlement Design. International Organization 54 (1):137-180.

Solingen, Etel. 2012. Of Dominoes and Firewalls: The Domestic, Regional, and Global Politics of International Diffusion. International Studies Quarterly 56 (4):631-644.

Spirling, Arthur. 2012. US treaty-making with American Indians. American Journal of Political Science 56 (1):84-97.

Starkey, Brigid, Mark A. Boyer, and Jonathan Wilkenfeld. 2005. Negotiating a Complex World: An Introduction to International Negotiation. Lanham, MD: Rowman and Littlefield.

Tallberg, Jonas., Thomas Sommerer, and Theresa Squatrito. 2015. Democratic Membership in International Organizations: Sources of Institutional Design. Review of International Organizations.

UNCTAD. 2015. World Investment Report 2015: Reforming International Investment Governance. Geneva: United Nations.

Vandevelde, Kenneth J. 1992. United States Investment Treaties: Policy and Practice. Cambridge: Kluwer Law International. 


\section{Appendix: Examples of Matching Text between PTAs}

\section{Red $=$ Matching Text \\ Black = Unmatched Text}

\section{1) Comparison of Armenia-Turkmenistan (1995) and Armenia-Moldova (1993) \\ Armenia-Turkmenistan \\ Armenia-Moldova}

Article 10

This Agreement shall not impede the right of any of the Contracting Parties to take generally accepted in the international practice measures which it considers necessary for protecting its vital interests or which are undoubtedly necessary for compliance with international agreements to which it is or intends to become a party, if these measures relate to:

- information affecting the interests of national defence, trade in arms, munitions and military equipment;

- research or production related to the defence needs;

- supply of materials and equipment used in nuclear industry;

- protection of public morality and public order;

- protection of industrial and intellectual property;

- gold, silver, and other precious metals and stones;

- protection of human, animal and plant life.

Article 11

With the goal of pursuing coordinated policy of export control in relation to the third countries Contracting Parties shall conduct regular consultations and take mutually agreed measures for creation of effective system of export control.
Article 11

This Agreement shall not impede the right of any of the Contracting Parties to take generally accepted in the international practice measures which it considers necessary for protecting its vital interests or which are undoubtedly necessary for compliance with international agreements to which it is or intends to become a party, if these measures relate to:

- information affecting the interests of national defence;

- trade in arms, munitions and military equipment;

- research or production related to the defence needs;

- supply of materials and equipment used in nuclear industry;

- protection of public morality and public order;

- protection of industrial and intellectual property;

- gold, silver, and other precious metals and stones;

- protection of human, animal and plant life.

Article 12

With the goal of pursuing coordinated policy of export control in relation to the third countries Contracting Parties shall conduct regular consultations and take mutually agreed measures for creation of effective system of export control. 
Disputes between Contracting Parties related to interpretation or application of provisions of this Agreement shall be resolved by means of negotiations.

Contracting Parties shall endeavour to avoid conflicting situations in mutual trade.

Contracting Parties establish that claims and disputes between economic entities of both countries resulting from interpretation or implementation of commercial contracts or transactions, in case they cannot be settled amicably on the basis of consultations and negotiations and unless agreed otherwise, will be the exclusive competence of arbitration tribunals (permanent or ad hoc) established in the territory of Contracting Parties or the territory of the third states specified by the Parties having signed the contract.

The latter can also define the applicable substantive law, norms and procedures as well as the premises for the hearing of the case.

Each Contracting Party shall assure in its territory effective means to recognise and enforce arbitration awards.
Disputes between Contracting Parties related to interpretation or application of provisions of this Agreement shall be resolved by means of negotiations.

Contracting Parties shall endeavour to avoid conflicting situations in mutual trade.

Contracting Parties establish that claims and disputes between economic entities of both countries resulting from interpretation or implementation of commercial contracts or transactions, in case they cannot be settled amicably on the basis of consultations and negotiations and unless agreed otherwise, will be the exclusive competence of arbitration tribunals (permanent or ad hoc) established in the territory of Contracting Parties or the territory of the third states specified by the Parties having signed the contract.

The latter can also define the applicable substantive law, norms and procedures as well as the premises for the hearing of the case.

Each Contracting Party shall assure in its territory effective means to recognise and enforce arbitration awards. 


\section{2) Comparison of US-Colombia (2006) and US-Chile (2003)}

\section{United States-Colombia}

Article 2.5: Temporary Admission of Goods

1. Each Party shall grant duty-free temporary admission for the following goods, regardless of their origin:

(a) professional equipment, including equipment for the press or television, software, and broadcasting and cinematographic equipment, necessary for carrying out the business activity, trade, or profession of a person who qualifies for temporary entry pursuant to the laws of the importing Party;

(b) goods intended for display or demonstration;

(c) commercial samples and advertising films and recordings; and

(d) goods admitted for sports purposes.

2. Each Party shall, at the request of the person concerned and for reasons its customs authority considers valid, extend the time limit for temporary admission beyond the period initially fixed.

3. No Party may condition the duty-free temporary admission of a good referred to in paragraph 1 , other than to require that the good:

(a) be used solely by or under the personal supervision of a national or resident of another Party in the exercise of the business activity, trade, profession, or sport of that person;

(b) not be sold or leased while in its territory;

(c) be accompanied by a security in an amount no greater than the charges that would otherwise be owed on entry or final importation, releasable on exportation of the good;

(d) be capable of identification when exported;

\section{United States-Chile}

Article 3.7: Temporary Admission of Goods

1. Each Party shall grant duty-free temporary admission for:

(a) professional equipment, including equipment for the press or television, software and broadcasting and cinematographic equipment, necessary for carrying out the business activity, trade or profession of a business person who qualifies for temporary entry pursuant to the laws of the importing Party;

(b) goods intended for display or demonstration;

(c) commercial samples and advertising films and recordings; and

(d) goods admitted for sports purposes, regardless of their origin.

2. Each Party shall, at the request of the person concerned and for reasons deemed valid by its customs authority, extend the time limit for temporary admission beyond the period initially fixed.

3. Neither Party may condition the duty-free temporary admission of goods referred to in paragraph 1, other than to require that such goods:

(a) be used solely by or under the personal supervision of a national or resident of the other Party in the exercise of the business activity, trade, profession, or sport of that person;

(b) not be sold or leased while in its territory;

(c) be accompanied by a security in an amount no greater than the charges that would otherwise be owed on entry or final importation, releasable on exportation of the good;

(d) be capable of identification when exported; 
(e) be exported on the departure of the person referenced in subparagraph (a), or within such other period related to the purpose of the temporary admission as the Party may establish, or within one year, unless extended;

(f) be admitted in no greater quantity than is reasonable for its intended use; and

(g) be otherwise admissible into the Party's territory under its law.

4. If any condition that a Party imposes under paragraph 3 has not been fulfilled, the Party may apply the customs duty and any other charge that would normally be owed on the good plus any other charges or penalties provided for under its law.

5. Each Party shall adopt and maintain procedures providing for the expeditious release of goods admitted under this Article. To the extent possible, such procedures shall provide that when such a good accompanies a national or resident of the other Party who is seeking temporary entry, the good shall be released simultaneously with the entry of that national or resident.

6. Each Party shall permit a good temporarily admitted under this Article to be exported through a customs port other than that through which it was admitted.

7. Each Party shall provide that the importer or other person responsible for a good admitted under this Article shall not be liable for failure to export the good on presentation of satisfactory proof to the importing Party that the good has been destroyed within the original period fixed for temporary admission or any lawful extension.

8. Subject to Chapters Ten (Investment) and Eleven (Cross-Border Trade in Services):

(a) each Party shall allow a vehicle or container used in international traffic that enters its territory from the territory of another Party to exit its territory on any route that is reasonably related to the economic and prompt departure of such vehicle or container; (e) be exported on the departure of the person referenced in subparagraph (a), or within such other period, related to the purpose of the temporary admission, as the Party may establish, or within one year, unless extended;

(f) be admitted in no greater quantity than is reasonable for their intended use; and

(g) be otherwise admissible into the Party's territory under its laws.

4. If any condition that a Party imposes under paragraph 3 has not been fulfilled, the Party may apply the customs duty and any other charge that would normally be owed on the good plus any other charges or penalities provided for under its domestic law.

5. Each Party, through its customs authority, shall adopt procedures providing for the expeditious release of goods admitted under this Article. To the extent possible, such procedures shall provide that when such a good accompanies a national or resident of the other Party who is seeking temporary entry, the good shall be released simultaneously with the entry of that national or resident.

6. Each Party shall permit a good temporarily admitted under this Article to be exported through a customs port other than that through which it was admitted.

7. Each Party, through its customs authority, consistent with domestic law, shall relieve the importer or other person responsible for a good admitted under this Article from any liability for failure to export the good on presentation of satisfactory proof to customs authorities that the good has been destroyed within the original period fixed for temporary admission or any lawful extension.

8. Subject to Chapters Ten (Investment) and Eleven (Cross-Border Trade in Services):

(a) each Party shall allow a vehicle or container used in international traffic that enters its territory from the territory of the other Party to exit its territory on any route that is reasonably related to the economic and prompt departure of such vehicle or container; 
(b) no Party may require any security or impose any penalty or charge solely by reason of any difference between the port of entry and the port of departure of a vehicle or container;

(c) no Party may condition the release of any obligation, including any security, that it imposes in respect of the entry of a vehicle or container into its territory on its exit through any particular port of departure; and

(d) no Party may require that the vehicle or carrier bringing a container from the territory of another Party into its territory be the same vehicle or carrier that takes the container to the territory of another Party.

9. For purposes of paragraph 8, vehicle means a truck, a truck tractor, a tractor, a trailer unit or trailer, a locomotive, or a railway car or other railroad equipment.

\section{Article 2.10: Administrative Fees and Formalities}

1. Each Party shall ensure, in accordance with Article VIII:1 of the GATT 1994 and its interpretive notes, that all fees and charges of whatever character (other than customs duties, charges equivalent to an internal tax or other internal charge applied consistently with Article III:2 of the GATT 1994, and antidumping and countervailing duties) imposed on or in connection with importation or exportation are limited in amount to the approximate cost of services rendered and do not represent an indirect protection to domestic goods or a taxation of imports or exports for fiscal purposes.

2. No Party may require consular transactions, including related fees and charges, in connection with the importation of any good of another Party.

3. Each Party shall make available and maintain through the Internet a current list of the fees and charges it imposes in connection with importation or exportation.

4. The United States shall eliminate its Merchandise Processing Fee on originating goods of Colombia upon the entry into force of this Agreement. (b) neither Party may require any bond or impose any penalty or charge solely by reason of any difference between the port of entry and the port of departure of a vehicle or container;

(c) neither Party may condition the release of any obligation, including any bond, that it imposes in respect of the entry of a vehicle or container into its territory on its exit through any particular port of departure; and

(d) neither Party may require that the vehicle or carrier bringing a container from the territory of the other Party into its territory be the same vehicle or carrier that takes such container to the territory of the other Party.

9. For purposes of paragraph 8, vehicle means a truck, a truck tractor, tractor, trailer unit or trailer, a locomotive, or a railway car or other railroad equipment.

Article 3.12: Administrative Fees and Formalities

1. Each Party shall ensure, in accordance with Article VIII:1 of GATT 1994 and its interpretive notes, that all fees and charges of whatever character (other than customs duties, charges equivalent to an internal tax or other internal charge applied consistently with Article III:2 of GATT 1994, and antidumping and countervailing duties) imposed on or in connection with importation or exportation are limited in amount to the approximate cost of services rendered and do not represent an indirect protection to domestic goods or a taxation of imports or exports for fiscal purposes.

2. Neither Party may require consular transactions, including related fees and charges, in connection with the importation of any good of the other Party.

3. Each Party shall make available through the Internet or a comparable computer-based telecommunications network a current list of the fees and charges it imposes in connection with importation or exportation.

4. The United States shall eliminate its merchandise processing fee on originating goods of Chile. 


\section{Article 2.12: Distinctive Products}

1. Colombia shall recognize Bourbon Whiskey and Tennessee Whiskey, which is a straight Bourbon Whiskey authorized to be produced only in the State of Tennessee, as distinctive products of the United States. Accordingly, Colombia shall not permit the sale of any product as Bourbon Whiskey or Tennessee Whiskey, unless it has been manufactured in the United States in accordance with the laws and regulations of the United States governing the manufacture of Bourbon Whiskey and Tennessee Whiskey.

\section{Article 3.15: Distinctive Products}

1. Chile shall recognize Bourbon Whiskey and Tennessee Whiskey, which is a straight Bourbon Whisky authorized to be produced only in the State of Tennessee, as distinctive products of the United States. Accordingly, Chile shall not permit the sale of any product as Bourbon Whiskey or Tennessee Whiskey, unless it has been manufactured in the United States in accordance with the laws and regulations of the United States governing the manufacture of Bourbon Whiskey and Tennessee Whiskey. 


\section{3) Comparison of European Communities-Montenegro (2007) and European Communities- Albania (2006)}

\section{$\underline{\text { EC-Montenegro }}$}

\section{ARTICLE 7}

The Parties reaffirm the importance that they attach to the fight against terrorism and the implementation of international obligations in this area.

\section{ARTICLE 15}

Cooperation with other countries having signed a Stabilisation and Association Agreement

After the signature of this Agreement, Montenegro shall start negotiations with the countries which have already signed a Stabilisation and Association Agreement with a view to concluding bilateral conventions on regional cooperation, the aim of which shall be to enhance the scope of cooperation between the countries concerned.

The main elements of these conventions shall be:

(a) political dialogue;

(b) the establishment of free trade areas, consistent with relevant WTO provisions;

(c) mutual concessions concerning the movement of workers, establishment, supply of services, current payments and movement of capital as well as other policies related to movement of persons at an equivalent level to that of this Agreement;

(d) provisions on cooperation in other fields whether or not covered by this Agreement, and notably the field of Justice, Freedom and Security.

These conventions shall contain provisions for the creation of the necessary institutional mechanisms, as appropriate.

\section{EC-Albania}

\section{ARTICLE 5}

The Parties reaffirm the importance that they attach to the fight against terrorism and the implementation of international obligations in this area.

\section{ARTICLE 13}

Cooperation with other countries having signed a Stabilisation and Association Agreement

After the signature of this Agreement, Albania shall start negotiations with the countries which have already signed a Stabilisation and Association Agreement with a view to concluding bilateral Conventions on regional cooperation, the aim of which shall be to enhance the scope of cooperation between the countries concerned.

The main elements of these conventions shall be:

$$
\begin{aligned}
& \text { - } \quad \text { political dialogue; } \\
& \text { - } \quad \text { the establishment of a free trade area } \\
& \text { between the Parties, consistent with the relevant } \\
& \text { WTO provisions; }
\end{aligned}
$$

- $\quad$ mutual concessions concerning the movement of workers, establishment, supply of services, current payments and movement of capital as well as other policies related to movement of persons at an equivalent level to that of this Agreement;

- $\quad$ provisions on cooperation in other fields whether or not covered by this Agreement, and notably the field of Justice and Home Affairs.

These Conventions shall contain provisions for the creation of the necessary institutional mechanisms, as appropriate. 


\section{4) Comparison of US-Panama (2007) and US-Colombia (2006)}

\section{$\underline{\text { United States-Panama }}$}

Article 3.18: Sugar Compensation Mechanism

1. In any year, the United States may, at its option, apply a mechanism that results in compensation to Panama's exporters of sugar goods in lieu of according duty-free treatment to some or all of the duty-free quantities of sugar goods established for Panama in paragraph 6 of Appendix I to the General Notes of the Schedule of the United States to Annex 3.3. Such compensation shall be equivalent to the estimated economic rents that Panama's exporters would have obtained on exports to the United States of any such amounts of sugar goods and shall be provided within 30 days after the United States exercises this option. The United States shall notify Panama at least 90 days before it exercises this option and, on request, shall enter into consultations with Panama regarding application of the mechanism.

\section{$\underline{\text { United States-Colombia }}$}

Article 2.19: Sugar Compensation Mechanism

1. In any year, the United States may, at its option, apply a mechanism that results in compensation to a Party's exporters of sugar goods in lieu of according duty-free treatment to some or all of the duty-free quantity of sugar goods established for that Party in Appendix I to the Schedule of the United States to Annex 2.3. Such compensation shall be equivalent to the estimated economic rents the Party's exporters would have obtained on exports to the United States of any such amounts of sugar goods and shall be provided within 30 days after the United States exercises this option. The United States shall notify the Party at least 90 days before it exercises this option and, on request, shall enter into consultations with the Party regarding application of the mechanism. 